\title{
Pelaksanaan program praktek kerja industri dalam penguasaan kompetensi keahlian administrasi perkantoran
}

\section{(Implementation of industrial practice program on the exposure of competence skills of office administrative)}

\author{
Rika Lisnawati', Adman ${ }^{2 *}$ \\ 1,2Program Studi Pendidikan Manajemen Perkantoran, \\ Fakultas Pendidikan Ekonomi dan Bisnis, Universitas Pendidikan Indonesia \\ Jl. Dr. Setiabudhi, No. 229 Bandung, Jawa Barat Indonesia \\ Email: adman@upi.edu
}

\begin{abstract}
ABSTRAK
Penelitian ini dilatarbelakangi rendahnya tingkat penguasaan kompetensi keahlian Administrasi Perkantoran oleh peserta didik pada Program Keahlian Administrasi Perkantoran. Tujuan dari penelitian ini adalah untuk memperoleh gambaran mengenai efektivitas pelaksanaan program praktek kerja industri, memperoleh gambaran mengenai tingkat penguasaan kompetensi keahlian administrasi perkantoran oleh peserta didik, dan untuk mengetahui apakah ada pengaruh dari efektivitas pelaksanaan program praktek kerja industri terhadap penguasaan kompetensi keahlian administrasi perkantoran oleh peserta didik. Penelitian ini menggunakan pendekatan kuantitatif. Metode penelitian yang digunakan adalah metode survey eksplanasi. Teknik pengumpulan data dilakukan melalui kuesioner. Anggota sampel yaitu 58 peserta didik yang sudah melaksanakan program prakerin pada Program Keahlian Administrasi Perkantoran. Teknik analisis data yang digunakan dalam penelitian adalah uji regresi linier sederhana. Berdasarkan hasil penelitian, didapatkan informasi bahwa pelaksanaan program praktek kerja industri berada pada kategori sangat efektif dan penguasaan kompetensi administrasi perkantoran oleh peserta didik berada pada kategori tinggi. Selain itu, hasil penelitian membuktikan bahwa terdapat pengaruh yang positif dan signifikan antara efektivitas pelaksanaan prakerin terhadap penguasaan kompetensi keahlian administrasi perkantoran oleh peserta didik sebesar $17,78 \%$ pada pada Program Keahlian Administrasi Perkantoran. Berdasarkan hasil penelitian, maka sarannya adalah agar pihak-pihak yang terlibat dalam pelaksanaan prakerin mempertahankan dan atau meningkatkan efektivitas pelaksanaan prakerin guna meningkatkan penguasaan kompetensi keahlian Administrasi Perkantoran oleh peserta didik terutama dalam aspek pengawasan dan bimbingan oleh tenaga/pembimbing dari pihak sekolah dan industri terhadap peserta didik selama pelaksanaan prakerin.
\end{abstract}

Kata Kunci: Prakerin; Kompetensi Administrasi Perkantoran

Received: Februari 2019, Revision: Mei 2019, Published: Juli 2019

\footnotetext{
*Corresponding author Copyright (c) 2019, EISSN 2656- 4734
} 


\begin{abstract}
This research is motivated by low level of competency skill of Office Administration skill by learner on Office Administration. The purpose of this study is to obtain a description of the effectiveness of the implementation of industrial work programs, obtain a description of the level of control of the competence of office administration expertise by learners, and to determine whether there is influence from the effectiveness of the implementation of industrial work programs to mastering the competence of administrative office skills by participants educate. This study uses a quantitative approach. The research method used is explanatory survey method. Data collection techniques were conducted through questionnaires. Members of the sample are 58 learners who have implemented prakerin program on Office Administration. Data analysis technique used in this research is simple linear regression test. Based on the results of research, obtained information that the implementation of industrial work programs in the category of very effective and control of the competence of office administration by students are in the high category. In addition, the results of the study prove that there is a positive and significant influence between the effectiveness of prakerin implementation to the mastery of the competence of office administration expertise by the learners of $17.78 \%$ in the Office Administration. Based on the results of the research, the authors suggest that the parties involved in the implementation of prakerin maintain and or improve the effectiveness of prakerin implementation in order to improve the mastery of the competence of administrative skills of the Office by the learners, especially in the supervision and guidance by the school / industry supervisor / mentor to the participants educated during prakerin implementation.
\end{abstract}

Keywords: Prakerin; Office Administration Competency

\title{
PENDAHULUAN
}

Semakin ketatnya persaingan dalam pasar kerja menuntut setiap sumber daya manusia (SDM) memiliki kompetensi-kompetensi tertentu yang sesuai dengan pasar kerja. Salah satu yang berperan penting dalam pencetakan SDM yang berkualitas adalah dunia pendidikan. Namun pada saat ini, efektivitas penyelenggaraan pendidikan dianggap masih kurang optimal, hal ini ditunjukkan dengan masih tingginya jumlah lulusan yang tidak terserap oleh lapangan kerja yaitu sebanyak 7.031.775 orang. Banyak faktor yang melatarbelakangi ketidakterserapan lulusan ini, salah satunya adalah kompetensi.

Hall dan Jones (1976) (dalam Masnur, 2009, hlm. 14), mengungkapkan bahwa "Kompetensi adalah pernyataan yang menggambarkan penampilan suatu kemampuan tertentu secara bulat yang merupakan perpaduan antara pengetahuan dan kemampuan yang dapat diamati dan diukur". Kompetensi ini meliputi kemampuan kognitif, afektif dan psikomotor.

Salah satu hal penting yang harus diperhatikan dari kompetensi adalah bahwa kompetensi yang dimiliki ini harus dapat memenuhi standar yang ada. Seseorang akan mengalami kesulitan dalam memasuki dunia kerja apabila kompetensi yang ia miliki 
tidak dapat memenuhi standar yang dipersyaratkan oleh dunia kerja tersebut. Untuk itu, peningkatan kompetensi menjadi hal yang perlu diprioritaskan.

Upaya peningkatan kompetensi SDM, dunia pendidikan pada umumnya dan pendidikan kejuruan pada khususnya memiliki peran yang sangat penting. Pendidikan kejuruan merupakan suatu sistem pendidikan yang memfokuskan kegiatannya pada pengembangan kompetensi peserta didik pada bidang tertentu yang diminati sehingga mereka dapat lebih siap untuk memasuki dunia kerja.

Untuk mendukung ketercapaian tujuan diadakannya pendidikan kejuruan, negara mengeluarkan kebijakan penyelennggaraan pendidikan sistem ganda (PSG). Penyelenggaraan PSG mengharuskan adanya kerjasama antara dunia pendidikan dan dunia usaha atau dunia industri baik dalam penyelenggaraan pendidikan maupun dalam pengembangan kurikulum SMK. Tujuannya adalah agar lulusan yang tercetak memiliki kualifikasi yang sesuai dengan kebutuhan pasar kerja karena proses pendidikan yang dilaksanakan berorientasi pada kebutuhan pasar. Pendidikan sistem ganda ini diimplementasikan dalam kegiatan praktek kerja industri.

Berdasarkan pemaparan diatas, dapat dirumuskan permasalahan sebagai berikut: 1) Bagaimana gambaran tingkat efektivitas pelaksanaan program Praktek Kerja Industri Program Keahlian Administrasi Perkantoran?, 2) Bagaimana gambaran tinggi rendahnya penguasaan kompetensi Keahlian Administrasi Perkantoran oleh peserta didik di Program Keahlian Administrasi Perkantoran?, 3) Adakah pengaruh efektivitas pelaksanaan program Praktek Kerja Industri terhadap tinggi rendahnya penguasaan kompetensi Keahlian Administrasi Perkantoran oleh peserta didik di Program Keahlian Administrasi Perkantoran?

Tujuan penelitian ini adalah untuk: 1) Mengetahui bagaimana gambaran tingkat efektivitas pelaksanaan program Praktek Kerja Industri Program Keahlian Administrasi Perkantoran, 2) Mengetahui bagaimana gambaran tingkat penguasaan kompetensi Keahlian Administrasi Perkantoran oleh peserta didik di Program Keahlian Administrasi Perkantoran, 3) Mengetahui adakah pengaruh efektivitas pelaksanaan program Praktek Kerja Industri terhadap tingkat penguasaan kompetensi Keahlian Administrasi Perkantoran oleh peserta didik di Program Keahlian Administrasi Perkantoran.

\section{TINJAUAN PUSTAKA}

Menurut teori belajar behaviorisme, belajar adalah perubahan tingkah laku sebagai akibat dari interaksi antara stimulus dan respon. Adapun tingkah laku yang dimaksud adalah tingkah laku atau perilaku yang dapat diamati atau diukur. Hingga kini, aliran psikologi ini memberikan pengaruh yang besar terhadap penyelenggaraan pendidikan.

Salah seorang penganut aliran psikologi behavior, Thorndike, mengungkapkan bahwa belajar merupakan peristiwa terbentuknya asosiasi-asosiasi antara peristiwaperistiwa yang disebut stimulus (S) dengan respon (R). Teori belajar Thorndike disebut juga teori koneksionisme atau $S-R$ Bond Theory atau $S-R$ Psycology of Learning atau Trial and Error Learning. Berdasarkan riset yang dilakukannya, Thorndike berkesimpulan bahwa subjek yang dihadapkan pada stimulasi tertentu secara berulang akan memberikan respon yang diharapkan dalam jangka waktu yang semakin sedikit. Maksud dari pernyataan tersebut adalah jika subjek dihadapkan pada situasi yang sama 
secara berulang-ulang, akan terjadi proses belajar melalui trial and error dimana subjek akan secara berkesinambungan mengeliminasi kesalahan-kesalahan yang dia lakukan dalam menghadapi situasi tersebut.

Adapun dalam penelitian ini akan dibahas mengenai pengaruh pelaksanaan program praktek kerja industri sebagai stimulus bagi pebelajar terhadap peningkatan kompetensi peserta didik sebagai respon dari pelaksanaan prakerin.

\section{Penguasaan Kompetensi Keahlian Administrasi Perkantoran}

Dalam pembelajaran, peserta didik diharuskan untuk mampu mencapai kompetensi-kompetensi yang telah ditentukan oleh kurikulum. Dave Ulrich, Profesor dari University of Michigan (1995) (dalam Parulian Hutapea, 2008, hlm. 6), mendefinisikan kompetensi sebagai "pengetahuan, keterampilan atau kemampuan individu yang diperagakan". Serta Boyatzis (1982) (dalam Parulian Hutapea, 2008, hlm. 4) mengungkapkan bahwa kompetensi didefinisikan sebagai kapasitas yang ada pada seseorang yang bisa membuat orang tersebut mampu memenuhi apa yang disyaratkan oleh pekerjaan dalam suatu organisasi sehingga organisasi tersebut mampu mencapai hasil yang diharapkan.

Beberapa pengertian diatas dapat kita simpulkan bahwa kompetensi tidak hanya berfokus pada keterampilan (psikomotorik) seseorang tetapi kompetensi merupakan perpaduan antara kemampuan kognitif (pengetahuan), afektif (sikap) dan psikomotorik (keterampilan) yang memungkinkan seseorang untuk dapat melaksanakan suatu pekerjaan/tugas sesuai dengan standar tertentu yang disyaratkan.

Kemampuan kognitif memungkinkan seseorang dapat mengidentifikasi permasalahan dan mencari solusi dari permasalahan yang dihadapi. Kemampuan psikomotorik memungkinkan seseorang dapat mengimplementasikan solusi dari penyelesaian masalah yang sebelumnya didapat melalui proses berfikir. Sedangkan kemampuan afektif memungkinkan seseorang untuk dapat mengatur kapan ia dapat lebih banyak menggunakan logika dan kapan ia dapat menggunakan emosi dalam penyelesaian suatu masalah. Dengan kata lain, memiliki ketiga aspek kompetensi ini (kemapuan kognitif, afektif dan psikomotorik) akan memungkinkan seseorang untuk menjadi pribadi yang unggul serta perlu diingat bahwa seseorang akan dianggap kompeten apabila kompetensi yang ia miliki memenuhi standar-standar yang disyaratkan.

Adapun menurut Michael Zwell (2000, hlm. 56), faktor-faktor yang dapat mempengaruhi kecakapan kompetensi seseorang yaitu keyakinan dan nilai-nilai; keterampilan; pengalaman; karakteristik kepribadian; motivasi; isu emosional; kemampuan intelektual; dan budaya organisasi.

Bagi peserta didik, kompetensi-kompetensi yang wajib dikuasai dirumuskan dalam bentuk Standar Kompetensi Lulusan (SKL). Menurut Permendikbud No. 54 tahun 2013, "Standar Kompetensi Lulusan adalah kriteria mengenai kualifikasi kemampuan lulusan yang mencakup sikap, pengetahuan dan keterampilan". SKL ini kemudian diuraikan ke dalam indikator yang lebih spesifik yaitu dalam bentuk Kompetensi Inti (KI) yakni gambaran secara kategorial mengenai kompetensi dalam aspek sikap, pengetahuan, dan keterampilan yang harus dipelajari peserta didik untuk suatu jenjang sekolah, kelas, dan mata pelajaran (Permendikbud No. 65 tahun 2013) dan Kompetensi Dasar (KD) yakni kemampuan spesifik yang mencakup sikap, 
pengetahuan, dan keterampilan yang terkait muatan atau mata pelajaran (Permendikbud No. 65 tahun 2013) yang selanjutnya dijadikan sebagai acuan dalam penentuan pemenuhan standar kompetensi lulusan oleh peserta didik.

Selanjutnya menurut Ida Nuraida (2008, hlm. 8), "Manajemen Administrasi Perkantoran adalah ilmu yang berhubungan dengan perencanaan, pengorganisasian, pelaksanaan dan pengendalian segala hal yang berhubungan dengan daur hidup data dan informasi bisnis dalam perusahaan".

Berdasarkan pengertian tersebut dapat kita simpulkan bahwa kompetensi keahlian Administrasi Perkantoran merupakan seperangkat kemampuan yang diharapkan dapat dikuasai oleh peserta didik yang akan memungkinkan dirinya mampu melaksanakan kegiatan perencanaan, pengorganisasian, pelaksanaan, dan pengendalian segala hal yang berhubungan dengan daur hidup data dan informasi bisnis dalam perusahaan sesuai dengan standar yang ditetapkan oleh perusahaan tersebut. Informasi yang dikelola dalam kegiatan manajemen perkantoran merupakan suatu hal yang sangat dibutuhkan oleh setiap organisasi/perusahaan terutama dalam kegiatan pengambilan keputusan. Kualitas dari informasi yang dimiliki organisasi akan sangat berpengaruh terhadap kelangsungan organisasi karena kualitas informasi akan berdampak pada baik atau buruknya keputusan yang diambil oleh perusahaan.

Berdasarkan kurikulum 2013, kompetensi keahlian Administrasi Perkantoran yang diharapkan dapat dikuasai oleh peserta didik terangkum dalam beberapa mata pelajaran yang masuk dalam kelompok C (Peminatan). Mata pelajaran kelompok C (Peminatan Administrasi Perkantoran) terbagi menjadi tiga, yaitu:

- $\quad$ C1 : Dasar Bidang kejuruan

Terdiri dari mata pelajaran Pengantar Ekonomi dan Bisnis, Pengantar Administrasi Perkantoran, dan Pengantar Akuntansi.

- C2 : Dasar Kompetensi Kejuruan

Terdiri dari mata pelajaran Otomatisasi Perkantoran, Korespondensi, Kearsipan, dan Simulasi Digital.

- $\quad$ C3 : Kompetensi Kejuruan

Terdiri dari mata pelajaran Administrasi Kepegawaian, Administrasi Keuangan, Administrasi Sarana dan Prasarana, serta Administrasi Humas dan Keprotokoleran.

Pada tahun 2016, kompetensi keahlian Administrasi perkantoran dalam kurikulum 2013 ini kemudian mengalami perubahan spektrum menjadi kompetensi keahlian Otomatisasi dan Tata Kelola Perkantoran dengan susunan mata pelajaran sebagai berikut:

- $\quad$ C1: Dasar Bidang Keahlian

Terdiri dari mata pelajaran Simulasi dan Komunikasi Digital, Ekonomi Bisnis, Administrasi Umum, dan IPA.

- C2: Dasar Program Keahlian

Terdiri dari mata pelajaran Teknologi Perkantoran, Korespondensi, dan Kearsipan.

- C3: Kompetensi Keahlian

Terdiri dari mata pelajaran Otomatisasi Tata Kelola Kepegawaian, Otomatisasi Tata Kelola Keuangan, Otomatisasi Tata Kelola Sarana dan Prasarana, 
Otomatisasi Tata Kelola Humas dan Keprotokolan, dan Produk Kreatif dan Kewirausahaan.

Dalam penelitian ini tidak semua kompetensi keahlian Administrasi Perkantoran diteliti, penelitian akan difokuskan pada kompetensi yang masuk dalam kategori peminatan C2 (Dasar Kompetensi Kejuruan) dan C3 (Kompetensi Kejuruan) pada kurikulum 2013.

\section{Praktek Kerja Industri}

Semakin ketatnya persaingan dalam pasar kerja menuntut setiap sumber daya manusia memiliki kompetensi-kompetensi tertentu yang sesuai dengan pasar kerja. Salah satu upaya negara dalam pemenuhan sumber daya manusia yang berkualitas adalah dengan penyelenggaraan pendidikan kejuruan. Menurut Undang-Undang Nomor 20 Tahun 2003 tentang Sistem Pendidikan Nasional pasal 15 dalam (Tim pengembang ilmu pendidikan FIP-UPI, 2007, hlm. 330) menyebutkan bahwa "Pendidikan kejuruan adalah pendidikan menengah yang mempersiapkan peserta didik terutama untuk bekerja dalam bidang tertentu". Melalui pendidikan kejuruan, peserta didik dapat mendalami program keahlian tertentu dan mempelajari setiap kompetensi yang diajarkan dalam program keahlian tersebut. Terfokusnya kompetensi-kompetensi yang dipelajari oleh peserta didik dalam sistem pendidikan kejuruan ini akan membuat mereka memiliki daya saing yang kuat saat memasuki lapangan kerja.

Selain itu, untuk menyelaraskan kompetensi yang diajarkan disekolah dengan kompetensi yang dibutuhkan oleh dunia usaha dan dunia industri, pemerintah mewajibkan setiap Sekolah Menengah Kejuruan (SMK) untuk menyelenggarakan pendidikan sistem ganda (PSG) dimana dalam pelaksanaan PSG ini menuntut keterlibatan secara aktif dunia usaha/dunia industri (DU/DI) dalam pengembangan kompetensi peserta didik sehingga pada akhirnya akan tercetak peserta didik yang dapat memenuhi kualifikasi dan kebutuhan pasar kerja. Pendidikan sistem ganda pada saat ini diimplementasikan dalam kegiatan Praktek Kerja Industri (Prakerin).

Prakerin merupakan suatu metode mengajar dimana dalam pelaksanaannya sekolah dan pihak DU/DI saling bekerja sama guna memberikan pengalaman kerja pada peserta didik dengan harapan hal tersebut akan dapat meningkatkan kompetensi mereka. Hal ini sesuai dengan yang diungkapkan oleh Istu Harjono (tesis, 2012, hlm. 47) yaitu "Praktek kerja industri adalah suatu bentuk penyelenggaraan pendidikan dan pelatihan kejuruan yang memadukan kegiatan belajar di sekolah dan kegiatan belajar melalui bekerja langsung pada bidang serta suasana sesungguhnya dan relevan di dunia kerja/industri”.

Pelaksanaan prakerin menurut Akhmad Karyono (jurnal, 2009, hlm. 168) dilakukan dengan tujuan untuk meningkatkan kualitas sumber daya manusia Sekolah Menengah Kejuruan (SMK) guna mewujudkan kesiapan tenaga kerja yang terampil, kompeten, kreatif, dan produktif dengan meningkatkan peran serta dunia industri dalam pelaksanaannya. Oleh karena itu, pelaksanaan prakerin ini menjadi sesuatu hal yang sangat penting untuk dilakukan dalam proses membentuk kualitas sumber daya manusia Sekolah Menengah Kejuruan (SMK).

Lama pelaksanaan prakerin berbeda-beda antara sekolah yang satu dan sekolah yang lainnya (disesuaikan dengan kesepakatan antara pihak sekolah dan pihak industri). Namun pada Spektrum Pendidikan Menengah Kejuruan tahun 2016, pemerintah 
menetapkan bahwa lama pelaksanaan prakerin harus berkisar antara 6 bulan sampai dengan 12 bulan, sesuai dengan jenis dan karakteristik kompetensi keahlian serta prakerin ini dilaksanakan pada akhir semester 4 dan atau awal semester 5 dengan pelaksanaan prakerin dapat dilaksanakan 1 kali atau 2 kali tergantung pada ketersediaan Dunia Usaha/Dunia Industri dan karakteristik kompetensi keahlian.

Kegiatan prakerin dapat dilaksanakan dengan model days release yakni dari enam hari belajar dalam setiap minggunya kegiatan belajar dilakukan di dua tempat yakni beberapa hari di sekolah dan beberapa hari di industri, blocks release yakni prakerin dilakukan pada bulan atau semester tertentu yang disepakati oleh sekolah dan institusi pasangannya, hours release yakni sekolah dan institusi pasangannya menyepakati jamjam peserta didik belajar di sekolah dengan jam-jam peserta didik belajar di industri, atau kombinasi dari ketiganya.

Agar pelaksanaan prakerin dapat berjalan dengan lancar serta membuahkan hasil yang sesuai dengan tujuan pelaksanaannya (efektif), program ini haruslah di manage dengan baik. Mulyasa (dalam Eling Damayanti, 2014, hlm. 102) menyebutkan manajemen Prakerin dapat diartikan sebagai segala sesuatu yang berkenaan dengan pengelolaan proses praktek kerja industri untuk mencapai tujuan yang telah ditetapkan, baik tujuan jangka pendek, menengah, maupun tujuan jangka panjang. Manajemen praktek kerja industri merupakan proses kegiatan merencanakan, mengorganisasikan, hingga mengevaluasi suatu program pembelajaran di sekolah dan di dunia industri yang melalui pelatihan dan pembelajaran guna untuk meningkatkan kompetensi keahlian yang dimiliki siswa.

Selain itu, menurut Made Wena (1996, hlm. 229), indikator-indikator efektivitas praktek kerja industri meliputi "Perencanaan praktek kerja industri, pengorganisasian praktek kerja industri, penyelenggaraan praktek kerja industri dan pengawasan praktek kerja industri”. Berdasarkan dari pemaparan diatas, dalam pelaksanaan prakerin pihak sekolah dan pihak DU/DI harus bekerja-sama agar prakerin yang dilaksanakan sesuai dengan kebutuhan sekolah dan DU/DI. Kemudian agar prakerin yang dilaksanakan mendatangkan hasil yang sesuai dengan tujuan pelaksanaannya maka proses perencanaan, pengorganisasian, penyelenggaraan dan pengawasan prakerin tersebut harus dilakukan dengan sebaik-baiknya.

\section{METODOLOGI}

Metode penelitian menggunakan metode survey eksplanasi (explanatory survey) dengan pendekatan kuantitatif. Sampel dalam penelitian ini adalah peserta didik kelas XII Program Keahlian Administrasi Perkantoran di SMKN 11 Bandung yang telah mengikuti kegiatan Praktek Kerja Industri sebanyak 58 orang yang diambil dengan menggunakan teknik Proportional Random Sampling. Instrumen yang digunakan dalam pengumpulan data berupa angket tertutup dengan model skala Likert yang sebelumnya sudah diuji validitas dan reliabilitasnya.

Data yang telah dikumpulkan selanjutnya dianalisis dengan menggunakan uji regresi linier sederhana. Sebelum melakukan uji regresi, terlebih dahulu dilakukan uji normalitas, uji homogenitas dan uji linieritas data.

Selanjutnya untuk menguji hipotesis dilakukan dengan langkah-langkah sebagai berikut: 1) Menentukan hipotesis statistik, 2) Menentukan taraf kemaknaan/nyata $\alpha$ (level of significance $\alpha$ ), 3) Menghitung nilai F, 4) Menentukan titik kritis dan daerah 
kritis (daerah penolakan) $\mathrm{H}_{0}, 5$ ) Membandingkan nilai uji $\mathrm{F}$ dengan nilai tabel $\mathrm{F}, 6$ ) Membuat kesimpulan.

\section{HASIL PENELITIAN DAN PEMBAHASAN}

Berdasarkan permasalahan yang hendak dijawab dalam penelitian ini, maka dapat disajikan data sebagai berikut:

Permasalahan pertama yaitu "Bagaimana gambaran tingkat efektivitas pelaksanaan program Praktek Kerja Industri (PRAKERIN) Program Keahlian Administrasi Perkantoran di SMKN 11 Bandung?”. Berdasarkan perhitungan, diperoleh hasil seperti tampak pada tabel berikut ini:

Tabel 1.

Rekapitulasi Tanggapan Responden terhadap Variabel Efektivitas Pelaksanaan Prakerin

\begin{tabular}{|c|l|c|c|c|}
\hline No & \multicolumn{1}{|c|}{ Indikator } & Item Soal & Rata-rata & Kategori \\
\hline 1 & Perencanaan/persiapan & $1-4$ & 4.55 & Sangat Efektif \\
\hline 2 & Penyelenggaraan & $5-10$ & 4.51 & Sangat Efektif \\
\hline 3 & Pengawasan dan Evaluasi & $11-15$ & 4.35 & Sangat Efektif \\
\hline \multicolumn{3}{|c|}{ Rata-rata } & $\mathbf{4 . 4 7}$ & Sangat Efektif \\
\hline
\end{tabular}

Tabel di atas menunjukkan bahwa rata-rata skor jawaban responden untuk variabel efektivitas pelaksanaan prakerin yaitu sebesar 4,47. Apabila dihubungkan dengan skala penafsiran pada tabel rekapitulasi skor kriterium, maka angka tersebut berada pada rentang 4,20 - 5,00 atau berada pada kategori sangat efektif.

Dengan demikian dapat disimpulkan bahwa tingkat efektivitas pelaksanaan prakerin di SMK Negeri 11 Bandung cenderung berjalan dengan sangat efektif.

Permasalahan kedua yaitu "Bagaimana gambaran tinggi rendahnya penguasaan kompetensi Keahlian Administrasi Perkantoran oleh peserta didik di Program Keahlian Administrasi Perkantoran SMKN 11 Bandung?". Berdasarkan perhitungan, diperoleh hasil seperti tampak pada tabel berikut ini:

Tabel 2.

Rekapitulasi Tanggapan Responden terhadap Variabel Penguasaan Kompetensi Keahlian Administrasi Perkantoran

\begin{tabular}{|c|c|c|c|c|}
\hline No & Indikator & Item Soal & Rata-rata & Kategori \\
\hline 1 & $\begin{array}{l}\text { Tingkat kompetensi peserta didik } \\
\text { dalam mengaplikasikan otomatisasi } \\
\text { perkantoran }\end{array}$ & $1-14$ & 4.103 & Tinggi \\
\hline 2 & $\begin{array}{l}\text { Tingkat kompetensi peserta didik } \\
\text { dalam mengaplikasikan simulasi } \\
\text { digital }\end{array}$ & $15-26$ & 3.751 & Tinggi \\
\hline 3 & $\begin{array}{l}\text { Tingkat kompetensi peserta didik } \\
\text { dalam melakukan } \\
\text { korespondensi }\end{array}$ & $27-43$ & 4.212 & Sangat Tinggi \\
\hline
\end{tabular}




\begin{tabular}{|c|c|c|c|c|}
\hline 4 & $\begin{array}{l}\text { Tingkat kompetensi peserta didik } \\
\text { dalam mengelola sistem kearsipan }\end{array}$ & $44-58$ & 4.278 & Sangat Tinggi \\
\hline 5 & $\begin{array}{l}\text { Tingkat kompetensi peserta didik } \\
\text { dalam } \\
\text { administrasi kepegawaian }\end{array}$ & $59-68$ & 3.991 & Tinggi \\
\hline 6 & $\begin{array}{l}\text { Tingkat kompetensi peserta didik } \\
\text { dalam } \\
\text { administrasi keuangan }\end{array}$ & $69-74$ & 4.009 & Tinggi \\
\hline 7 & $\begin{array}{lcc}\text { Tingkat } & \text { kompetensi peserta } & \text { didik } \\
\text { dalam } & \text { mengaplikasikan } & \text { adm. } \\
\text { Sarpras } & & \\
\end{array}$ & $75-79$ & 4.172 & Tinggi \\
\hline 8 & $\begin{array}{l}\text { Tingkat komp. peserta didik dalam } \\
\text { mengaplikasikan adm. humas dan } \\
\text { keprotokoleran }\end{array}$ & $80-85$ & 4.057 & Tinggi \\
\hline \multicolumn{3}{|c|}{ Rata-rata } & 4.072 & Tinggi \\
\hline
\end{tabular}

Tabel di atas menunjukkan bahwa rata-rata skor jawaban responden untuk variabel tingkat penguasaan kompetensi keahlian administrasi perkantoran oleh peserta didik sebesar 4,072. Apabila dihubungkan dengan skala penafsiran pada tabel rekapitulasi skor kriterium, maka angka tersebut berada pada rentang 3,40 - 4,19 atau berada pada kategori tinggi.

Dengan demikian dapat disimpulkan bahwa tingkat penguasaan kompetensi keahlian administrasi perkantoran oleh peserta didik pada program keahlian administrasi perkantoran di SMK cenderung berada pada tingkat tinggi.

Permasalahan ketiga yaitu "Adakah pengaruh efektivitas pelaksanaan program Praktek Kerja Industri terhadap tinggi rendahnya penguasaan kompetensi Keahlian Administrasi Perkantoran oleh peserta didik di Program Keahlian Administrasi Perkantoran SMKN 11 Bandung?". Berdasarkan hasil analisis diperoleh bahwa terdapat pengaruh positif dari efektivitas pelaksanaan program Praktek Kerja Industri terhadap penguasaan kompetensi Keahlian Administrasi Perkantoran oleh peserta didik pada Program Keahlian Administrasi Perkantoran SMK melalui persamaan garis regresi $\hat{\mathrm{Y}}=$ $170,26+2,20(\mathrm{X})$ sebesar $17,78 \%$.

Pemaparan di atas menunjukkan bahwa efektivitas pelaksanaan prakerin memiliki pengaruh yang cukup kuat terhadap penguasaan kompetensi keahlian administrasi perkantoran oleh peserta didik pada Program Keahlian Administrasi Perkantoran di SMK 11 Bandung

\section{KESIMPULAN}

Berdasarkan hasil analisis dan pembahasan ditemukan hal-hal sebagai berikut: 1) Tingkat efektivitas pelaksanaan prakerin di SMK Negeri 11 Bandung cenderung berjalan dengan sangat efektif, 2) Tingkat penguasaan kompetensi keahlian administrasi perkantoran oleh peserta didik pada program keahlian administrasi perkantoran di SMK Negeri 11 Bandung cenderung berada pada tingkat tinggi, 3) Efektivitas pelaksanaan prakerin memiliki pengaruh yang cukup kuat terhadap penguasaan kompetensi keahlian administrasi perkantoran oleh peserta didik pada Program Keahlian Administrasi Perkantoran di SMK. 
Berdasarkan temuan-temuan di atas dapat disimpulkan bahwa pelaksanaan praktek kerja industri yang efektif akan disertai dengan kenaikan tingkat penguasaan kompetensi keahlian administrasi perkantoran oleh peserta didik pada Program Keahlian Administrasi Perkantoran di SMK.

Berdasarkan temuan-temuan penelitian yang telah dijelaskan dapat diberikan beberapa saran sebagai berikut: 1) Pihak sekolah dan DU/DI hendaknya terus mempertahankan dan atau meningkatkan efektivitas pelaksanaan prakerin dengan secara berkesinambungan mengadakan evaluasi dan perbaikan proses pelaksanakan program praktek kerja industri terutama dalam aspek pengawasan dan bimbingan oleh tenaga/pembimbing dari pihak sekolah dan industri terhadap peserta didik selama pelaksanaan prakerin sehingga tujuan pelaksanaan program praktek kerja industri dapat terpenuhi/tercapai, 2) Penguasaan kompetensi keahlian administrasi perkantoran oleh peserta didik tersebut masih dapat ditingkatkan untuk memperolah hasil yang lebih optimal, terutama pada kompetensi peserta didik dalam mengaplikasikan simulasi digital yang memiliki tingkat persentase terendah. Dengan meningkatkan efektivitas pelaksanaan program prakerin diharapkan dapat meningkatkan penguasaan kompetensi keahlian administrasi perkantoran oleh peserta didik. Untuk itu semua pihak yang terlibat dalam proses pelaksanaan prakerin harus memperhatikan faktor efektivitas pelaksanaan prakerin guna meningkatkan penguasaan kompetensi keahlian administrasi perkantoran oleh peserta didik, 3) Bagi sekolah yang akan melakukan penelitian yang lebih mendalam mengenai efektivitas pelaksanaan prakerin dan penguasaan kompetensi administrasi perkantoran oleh peserta didik diharapkan dapat melakukan penelitian dengan sampel yang lebih luas dan menambah variabel lain yang tidak diteliti dalam penelitian ini.

\section{DAFTAR PUSTAKA}

Damayanti, Eling. (2014). Manajemen Praktek Kerja Industri pada Kompetensi Keahlian Administrasi Perkantoran di SMK Se- Kota Yogyakarta. Skripsi. Yogyakarta: Fakultas Ilmu Pendidikan UNY.

Harjono, Istu. (2012). Implementasi Praktek Kerja Industri (Prakerin) pada Kompetensi Keahlian Teknik Instalasi Tenaga Listrik SMK Negeri 4 di Kota Tangerang. Tesis Magister Administrasi Universitas Indonesia. Jakarta: tidak diterbitkan.

Karyono, Akhmad. (2009). Kontribusi Status Industri Tempat Prakerin, Lama Prakerin, dan Motivasi Belajar Terhadap Sikap Kewirausahaan Siswa SMK di Kabupaten Indramayu. Teknologi dan Kejuruan. Vol. 32 No. 2. hl. 165-176.

Hutapea, Parulian dan Thoha, Nurrianna. (2008). Kompetensi Plus (Teori, Desain, Kasus dan Penerapan untuk HR serta Organisasi yang Dinamis). Jakarta: PT Gramedia Pustaka Utama.

Masnur. (2009). KTSP Pembelajaran Berbasis Kompetensi dan Kontekstual. Jakarta: Bumi Aksara.

Nuraida, Ida. (2008). Manajemen Administrasi Perkantoran. Yogyakarta: Kanisius.

Peraturan Menteri Pendidikan dan Kebudayaan RI No. 54/2013. Tentang Standar Kompetensi Lulusan Pendidikan Dasar dan Menengah. Jakarta: Republik Indonesia.

Peraturan Menteri Pendidikan dan Kebudayaan RI No. 65/2013. Tentang Standar Proses Pendidikan Dasar dan Menengah. Jakarta: Republik Indonesia. 
Undang-undang Republik Indonesia No. 20/2003. Tentang Sistem Pendidikan Nasional. Jakarta: Republik Indonesia.

Wena, Made. (1996). Pendidikan Sistem Ganda. Bandung: Tarsito.

Zwell, Michael. 2000. Creating a Culture of Competence. New York: John Wiley \& Sons, Inc. 